\title{
Serum Concentration of Ghrelin, Oxidative Stress and Lipid Parameters in Obese Subjects
}

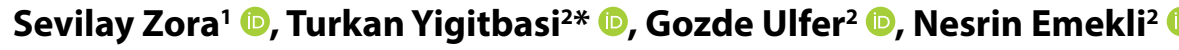 \\ 'Istanbul Aydın University, Vocational Faculty of Health Services, Istanbul, Turkey \\ Istanbul Medipol University, Faculty of Medicine, Department of Biochemistry, Istanbul, Turkey
}

ORCID IDs of the authors: S.Z. 0000-0002-6534-0538; T.Y. 0000-0002-0675-1839; G.U. 0000-0003-2350-6381; N.E. 0000-

0002-0109-5086.

Please cite this article as: Zora S, Yigitbasi T, Ulfer G, Emekli N. Serum Concentration of Ghrelin, Oxidative Stress and Lipid Parameters in Obese Subjects. Eur J Biol 2018; 77(2): 55-58.

\begin{abstract}
Objective: Ghrelin is a hormone with peptide structure. It has fatty tissue and increases appetite. Obesity is a multifactorial chronic disease characterized by an increase in fat tissue. Fat tissue, like the endocrine organ, triggers oxidative stress and can lead to the development of obesity-related pathologies. The purpose of this study is to examine the relationship between the ghrelin in blood, and oxidative stress and lipid parameters.

Materials and Methods: The study was conducted with 61 obese and 24 healthy individuals. Ghreline levels were measured using the ELISA method, while total antioxidant status (TAS) and oxidant status (TOS), triglyceride (TG), total cholesterol (TC), $\mathrm{HDL}$-cholesterol (HDL-C) and LDL cholesterol (LDL-C) levels were measured using the photometric method.

Results: A negative correlation was found between body mass index (BMI) and ghrelin levels in the obese group $(p<0.05)$. But there was no significant difference of ghrelin levels in obese and control groups ( $p>0.05)$. TAS was observed to be lower in obese compared to control group, while The Oxidative Stress Index (OSI) was found to be significantly higher than the obese group $(p<0.05)$. TG levels were found to be increased in obese; whereas ghrelin, TC, LDL-C and HDL-C levels did not show any difference $(p>0.05)$.
\end{abstract}

Conclusion: Increasing obesity level (BMI) and decreasing ghrelin level were found to be correlated. New studies are needed in order to discover the changes in ghrelin level connected to oxidative stress.

Keywords: Ghrelin, obesity, oxidative stress

\section{INTRODUCTION}

Obesity is an increase in the amount of fat in the body, which occurs when energy intake is more than energy spent.

Today fatty tissue is no more regarded as a mere fat storage since its carries an important duty. That is, it affects other organs and carries communication between them, therefore fatty tissue is regarded as an endocrine organ which synthesizes and releases many chemical messengers, the cytokine of fatty tissue (adipokine) (1-3).
In obesity, an increased fatty tissue brings many physical and biochemical pathologies $(1,2)$.

Ghrelin is an acylated peptide which contains 28 amino acids and it is primarily produced in the stomach and the proximal small intestine (4). Ghrelin activates the hypothalamus and other related systems in the brain, therefore increasing gastrointestinal motility and decreasing insulin secretion (5). The growth hormone secretagogue receptor (GHS-R) mediates the different actions of the synthetic growth hormone secretagogues (GHS) and the endogenous ligand of this

This study was presented at the $6^{\text {th }}$ World Congress of Oxidative Stress, Calcium Signaling and TRP Channels, 24-27 May 2016, Isparta, Turkey. 
receptor, ghrelin (6). This endogenous ligand for this GHS receptor (GHS-R) was generally identified by Kojima et al. in 1999 and named 'ghrelin' (7). Currently it's the only known oroxigenic hormone (8). Cancer patients with loss of appetite were reported to gain back appetite when administered ghrelin (9).

In healthy cells, oxidation of molecular oxygen is a well-controlled process. However, in cases of cell damage and disease, superoxide radical $\left(\mathrm{O}_{2}^{-}{ }^{-}\right)$and hydrogen peroxide $\left(\mathrm{H}_{2} \mathrm{O}_{2}\right)$ amounts increase. In the case of increased reactive oxygen radicals (ROS), insufficient antioxidants lead to oxidative stress. In the case of oxidative stress, proteins, lipids and DNA are damaged. Several studies report that increased oxidative stress in obesity contributes to development of atherosclerosis (10-14).

The aim of this study was to investigate the relationship between blood levels of ghrelin hormone, body mass index (BMI), oxidative stress and lipid parameters, which are important in carbohydrate and fat metabolism.

\section{MATERIALS AND METHODS}

\section{Study Design and Data Collection}

This study includes 24 controls ( 13 male and 11 female) and 61 obese ( 37 male and 24 female) who have consulted Mega Medipol Hospital Laboratory of Medipol University between September and October 2015. After taking the approval of ethical committee of Medipol University, all the patients were informed and confirmed consent documents were taken from all them. Groups were classified according to their BMl into two groups: $\mathrm{BMl}>18.9$ and $\mathrm{BMI}<24.9 \mathrm{~kg} / \mathrm{m}^{2}$ are considered as normal weight and $\mathrm{BMI}>30 \mathrm{~kg} / \mathrm{m}^{2}$ are considered as obese. BMl values were obtained by dividing the weight (in $\mathrm{kg}$ ) by the square of height $\left(\mathrm{m}^{2}\right)$.

The mean BMI $\left(\mathrm{kg} / \mathrm{m}^{2}\right)$ in the control group was 23.52 \pm 0.89 , while in the obese group it was $33.76 \pm 6.15$.

\section{Exclusion Criteria in the Study}

Exclusion criteria in the study was as follows: younger than 18, over 75 years old, smoking habits, hypertension, heart diseases, osteoarthritis, cancer, polycystic disease, inflammation and infectious diseases not included in the study. The study started after the approval of Medipol University Ethics Board. All the subjects were informed about the study and their approved consent forms were received.

\section{Blood Collection and Storage}

Venous blood was collected in the early morning before breakfast and after overnight sleep. Blood samples were collected in yellow covered flat tubes and purple covered (EDTA containing) tubes. Yellow covered tubes were centrifuged at $2400 \mathrm{rpm}$ for 10 minutes in the clinical biochemistry laboratory of Medipol University, and blood cells were separated from serum. Separated serums were taken into Eppendorf tubes and kept at $-80^{\circ} \mathrm{C}$ until the analysis.

\section{Methods Used}

Following analyses were carried out: Ghrelin, triglyceride (TG), total cholesterol (TC), low density lipoprotein cholesterol
(LDL-C), high density lipoprotein cholesterol (HDL-C), total antioxidant status (TAS), total oxidant status (TOS) and oxidative stress index (OSI) levels.

Serum ghrelin levels were determined by using Ray Bio EIAGHR-1 Elisa kit; TAS and TOS were determined by colorimetric method. OSI was calculated using the formula given below: OSI $=\left[\left(T O S, \mu \mathrm{mol} \mathrm{H}_{2} \mathrm{O}_{2}\right.\right.$ equivalent/l)/(TAS, $\mu \mathrm{mol}$ Trolox equivalent/I)] x100 (15). Serum TC, HDL-C, LDL-C and TG levels were measured with Roche/Hitachi C501 instrument photometrically with the kits recommended by the instrument company.

\section{Statistical Analysis}

The Statistical Package for the Social Sciences (SPSS) Windows version 22.0 (IBM Corp.; Armonk, NY, USA) program was used to evaluate the statistical analysis of the study. Variables were defined in \pm SD limits. T-test was used for the comparison of measured variable average values that obey normal distribution, in two groups. In order to compare dependent variables paired t-test was applied. Also, Mann-Whitney U-test was preferred to compare the average values obtained that do not obey normal distribution. For all the test $\mathrm{p}<0.05$ was considered significant.

\section{RESULTS}

As it was shown in Table 1, there was no significant change in the plasma levels of ghrelin ( $p>0.05)$ in obese and control groups.

Serum TG levels were increased in obese group $(p<0.05)$ whereas other lipid parameters such as TC, LDL-C and HDL-C were normal levels ( $p>0.05)$.

There was a significant decrease in serum TAS in obese group $(p<0.001)$, serum TOS were not significantly changed $(p>0.05)$ and OSI were significantly high in obese compare to normal subjects.

When correlation analyses were examined, a positive relation was found between TOS and OSI $(r: 0.77, p<0.05)$ TOS and TG $(r: 0.52, p<0.05)$, a negative correlation was observed between TOS values and HDL ( $r:-0.34, p<0.05)$. In addition, positive relation was found between OSI and TG $(r: 0.33, p<0.05)$.

The plasma levels of ghrelin were significantly negatively correlated with BMI $(r:-2,65, p<0.05)$.

\section{DISCUSSION}

Known as the "orexigenic hormone", ghrelin maintains the energy balance of the organism together with neuroendocrine regulation, intestinal and pancreatic peptides $(4,5,16)$. Despite these systems for protecting the organism, the prevalence of obesity is increasing in the world. Obesity results in insulin resistance, inflammation, oxidative stress in parallel with increasing fat tissue (1).

In this study, we investigated the relationship between ghrelin serum concentration and oxidative stress and lipid parameters 
Table 1. Laboratory findings of control and obese group.

\begin{tabular}{|c|c|c|c|}
\hline & Control group (Mean \pm SD) & Obese group (Mean \pm SD) & $\mathbf{p}^{*}$ \\
\hline Ghrelin (pg/mL) & $110.78 \pm 25.46$ & $110.43 \pm 25.43$ & 0.955 \\
\hline TAS ( $\mu$ mol Trolox Equiv./L) & $0.92 \pm 0.11$ & $0.81 \pm 0.13$ & $<0.05$ \\
\hline TOS ( $\mu \mathrm{mol} \mathrm{H}_{2} \mathrm{O}_{2}$ Equiv./L) & $26.96 \pm 5.49$ & $28.26 \pm 6.31$ & 0.386 \\
\hline OSI (AU) & $2.92 \pm 0.62$ & $3.56 \pm 0.86$ & $<0.05$ \\
\hline $\mathrm{HDL}(\mathrm{mg} / \mathrm{dL})$ & $53.22 \pm 17.82$ & $47.65 \pm 13.52$ & 0.149 \\
\hline $\mathrm{LDL}(\mathrm{mg} / \mathrm{dL})$ & $119.35 \pm 34.45$ & $121.98 \pm 37.88$ & 0.768 \\
\hline $\mathrm{TG}(\mathrm{mg} / \mathrm{dL})$ & $126.14 \pm 82.92$ & $158.13 \pm 85.36$ & 0.033 \\
\hline $\mathrm{TC}(\mathrm{mg} / \mathrm{dL})$ & $195.46 \pm 41.36$ & $198.35 \pm 40.99$ & 0.771 \\
\hline
\end{tabular}

in the obese and healthy control group, which increased appetite and food intake.

Mucioli et al. (17) reported that ghrelin, one of the peptides in the appetite center, increases appetite and causes obesity. As reported by Kara et al. (18), Ghrelin injections to mice caused an increase in fat tissue by reducing fat use. Ghrelin's fat tissue and appetite-enhancing effects are independent of GH effects and are thought to be regulated by specific neurons in the CNS where leptin is also a mediator.

Wren et al. reported that when ghrelin is administered intravenously to normal weight healthy people, the desire to eat is increased. Blood levels of ghrelin decrease after fasting and after a sugary and fatty meal (5).

Tschöp et al. (19) reported that ghrelin levels were lower in obese subjects than in weaker subjects. In the Suematsu et al. study, ghrelin was measured in 17 obese and 17 healthy subjects and the ghrelin level was found to be lower in the obese group than in the control group (12). Participants had an increase in serum ghrelin levels as a result of their weight loss after the diet (14,17-19).

In the study of Cinaz et al. (20), hunger and satiety ghrelin levels were measured in 38 obese and 19 healthy children. In both obese and control groups fasting ghrelin levels were higher than satiety ghrelin levels $(p<0.05)$. The researchers also showed that the hunger and satiety ghrelin levels of obese children were lower than the control group $(p<0.05)$. The study also found a negative correlation between $\mathrm{BMI}$ and hunger strike levels in the obese group.

In our study, the ghrelin concentration was not statistically different in the control and obese group ( $p>0.05)$. However, increased obesity level (BMI) was found to be correlated with decreased ghrelin level $(r:-2.65 p<0.05)$. This situation is caused by positive energy balance which suppresses ghrelin secretion in obese people. This finding is consistent with stud- ies suggesting that ghrelin levels are reduced in obese individuals.

In our study, TAS was observed to be lower in obese compared to control group, while OSI was found to be significantly higher than the obese group $(p<0.05)$. Obese group with oxidative stress do not differ in terms of ghrelin levels ( $p>0.05)$. The only study in this area in the literature was reported by Suematsu et al. In their study, free 8-epi-prostaglandin $\mathrm{F}_{2 a}$ was measured as a systemic marker of oxidative stress and, independently from obesity, it was discovered that increases in oxidative stress decreases ghrelin (12).

In the literature, in general, ghrelin levels were found to be decreased in obese subjects, but the mechanism of this decrease has not been explained (19).

The LDL-C, HDL-C and TC levels did not significantly change when compared to control group and remained within the normal reference limits when the lipid profile in both groups were examined and TG levels were found to be statistically higher in the obese group $(p<0.05)$. Positive correlation between TG and TOS and OSI shows the role of TG increase in the formation of oxidative stress.

In conclusion, ghrelin levels did not significantly change in obese group when compared to control group. This situation is caused by positive energy balance suppresses ghrelin secretion in obese people. Understanding obesity and its associated diseases with the appetite hormone ghrelin will help to develop new strategies for the prevention of obesity. New studies are needed for guidance in this area.

Ethics Committee Approval: Ethics Committee Approval was received for this study from the ethics committee of Medipol University.

Informed Consent: Written informed consent was obtained from patients who participated in this study.

Peer-review: Externally peer-reviewed. 
Author Contributions: Concept - S.Z., T.Y., N.E.; Design - S.Z., T.Y., N.E.; Supervision - T.Y., N.E.; Resource - N.E.; Materials - N.E., G.Ü.; Data Collection and/or Processing - S.Z., G.Ü.; Analysis and/or Interpretation S.Z., T.Y., N.E.; Literature Search - S.Z., N.E.; Writing - S.Z., N.E.; Critical Reviews - T.Y., N.E.

Acknowledgements: The authors thank Çağrı Çakıcı and Feyza Bayramoğlu (Istanbul Medipol University, Faculty of Medicine) for their kind assistance for laboratory work.

Conflict of Interest: The authors have no conflict of interest to declare.

Financial Disclosure: This study was supported by Istanbul Medipol University Scientific Research Projects (Project No: 86770134-604-101).

\section{REFERENCES}

1. Yiğitbaşı T, Emekli N. Obezite Biyokimyası. İçinde: Klinik Biyokimya, Editörler: Emekli \& Yiğitbaşı, Akademi Basım Yayın, Yayımcı Nobel Tıp Kitabevleri 2015; 311-22.

2. Sikaris KA. The clinical bichemistry of obesity. Clin Biochem Review 2004; 25(3): 165-81.

3. Haslam D, Sattar N, Lean M. ABC of Obesity: obesity time to wake up. British Medical Journal 2014; 333(7569): 640-42.

4. Murphy KG, Bloom SR. Gut hormones and regulation of energy hemeostasis. Nature 2006; 444(7121): 854-59.

5. Wren AM, Seal LJ, Cohen MA, Brynes AE, Frost GS, Murphy KG, et al. Ghrelin enhances appetite and increases food intake in humans. J Clin Endocrinol Metab 2001; 86(12): 5992.

6. Noguerias R, Perez-Tilve D, Worrtley KE and Tschop M. Growth hormone secretagogue(ghrelin) receptors a complex drug target for the regulation of body weight. CNS Neurol Disord Drug Targets 2006; 5(3): 335-43.

7. Kojima $M$, Hosoda $H$, Date $Y$, Nakazato $M$, Matsuo $H$, Kangawa $\mathrm{K}$. Ghrelin is a growth hormone releasing acylated peptide from stomach. Nature 1999; 402(6762): 656-60.

8. Otto B, Cuntz U, Fruehauf E, Wawarta R, Fulwaczny C, Riepl RL, et al. Weight gain decreases elevated plasma ghrelin concentrations of patients with anoxia nervosa. Eur J Endocrinol 2001; 145(5): 669-73.
9. Neary NM, Small CJ, Wren AM, Lee JL, Druce MR, Palmieri C et al. Ghrelin increases energy intake in cancer patients with impaired appetite: acute, randomized, placebo controlled trial. J Clin Endocrinol Metab 2004;89(6): 2832-36.

10. Kim KA, Yim JE. Antioxidative activity of onion peel extract in obese women: A randomized, double-blind, placebo controlelled study. J Cancer Prev 2015; 20(3): 202-7.

11. Berliner JA, Navab M, Fogelman AM, Frank JS, Demer LL, Edwards PA, Watson AD, Lusis AJ. Atherosclerosis: basic mechanisms. Oxidation, inflammation, and genetics. Circulation 1995; 91(9): 2488-96.

12. Suematsu M, Katsuki A, Sumida Y, Gabazza EC, Murashima S, Matsumoto $\mathrm{K}$, et al. Decreased circulating levels of active ghrelin are associated with increased oxidative stress in obese subjects. Eur J Endocrinol 2005; 153(3): 403-7.

13. Hopps E, Noto D, Caim G, Averna MR. A novel component of the metabolic syndrome: The oxidative stress. Nutr Metab Cardiovasc Dis 2010; 20(1): 72-7.

14. Oner-lyidogan $Y$, Kocak H, Gurdol H, Oner P, Issever H, Esin D. Circulating ghrelin levels in obese women: a possible association with hypertension. Scand J Clin Lab Invest 2007; 67(5): 568-76.

15. Erel O. A new automated colorimetric method for measuring total oxidant status. Clin Biochem 2005; 38(12): 1103-11.

16. Chamber ES, Viardot A, Psichas A, Morrison DJ, Murphy KG, Zac-Varghese SEK, et al. Effects of targeted delivery of propionate to the human colon on appetite regulation, body weight maintenance and adiposity in overweight adults. Gut 2015; 64(11): 1744-54.

17. Mucioli G, Tschöp M, Papotti M, Deghenghi R, Himen M, Ghigo $E$. Neuroendoncrine and peripheral activities of ghrelin: implications in metabolism and obesity. Eur J Pharmacol 2003; 440(2-3): 235-54.

18. Kara $\mathrm{H}$. The relationship between weight loss and biochemical parameters such as leptin, ghrelin, nesfatin 1, obestatin in obese individuals. Balikesir University, Institute of Health Sciences, Department of Medical Biochemistry. Master Thesis, Balıkesir, 2014.

19. Tschöp M, Weyer C, Tataranni PA, Devanarayan V, Ravussin E, Heiman ML. Circulating ghrelin levels are decreased in human obesity. Diabetes 2001; 50(4): 707-9.

20. Cinaz P, Yesilkaya E, Kaya A. Plasma ghrelin, serum IGF-1 and IGFBP-3 levels in obese children. J Ist Faculty Med 2009; 72 (2): 47-51. 